\title{
KEARIFAN RITUAL DAN SOSIAL SYAIR-SYAIR SUFI
}

\author{
Ahmad Kholil \\ Jurusan Bahasa dan Sastra Arab, Fak. Humbud, UIN Maliki Malang \\ Email. khumi_01@yahoo.com
}

\begin{abstract}
Substantially, "Tasawuf" as the way towards God had been existing since the prophet age; but it was just at the end of the second Hijriyah this term that was known as zuhud became then popularly known as tasawuf. After Islam develops, marked by variety of traditions and sciences as the result of the contribution of various culture expressed through knowledge, tasawuf becomes clear in Islam. Some intellectuals don't see tasawuf as pure Islam, because some teachings related to certain rituals reflect some tradition and culture. Many intellectuals agreed to Nasr's opinion, and there are many western intellectuals know tasawuf (Sufism) better than Islam. Now tasawuf has been considered by many people as a universal spiritual value and it is as eternal as Islam. Syawqi Doif, an Arabic intellectual who wrote a lot about the history of Arabic culture and literature, in his book entitled al-Tarikh al-Adab fi al-Ashr al-Abbasyi alTsani, especially about zuhud and tasawuf. This paper discussed about tasawuf followed by poems written by mutashawwifin discussing about sufi's terms. Many sufis left behind them literary works which describe the way they believe. The writer quoted and discussed some poems based on his understanding.
\end{abstract}

\section{Keywords}

Sufism, Tasawuf

\section{Pendahuluan}

Di masa kita saat ini, abad 21, era kecanggihan teknologi, suatu masa di mana telah tampak nyata membawa orang terasing (alienasi) dari dirinya sendiri, perdebatan tentang sastra Islam masih terus berlangsung antara ada atau tidaknya, bahkan antara perlu dan tidaknya. Terlepas dari perdebatan itu, bagi saya, sudah pasti manusia modern yang terasing itu membutuhkan sentuhan nilai-nilai Islam untuk kemudian dapat menerapkan dalam kehidupannya agar mereka tidak asing atau diasingkan. Nilai-nilai Islam yang perlu diwujudkan itu dapat digali dari berbagai sumber dari ayat-ayat Tuhan yang terhampar luas baik dalam wujud tulisan dari ayatayat suci maupun kitab-kitab lain yang isinya mengajak kepada keimanan dan juga ayat-ayat kawniyah yang berupa fenomena alam yang mandiri berupa gejala alam yang lahir tanpa campur tangan manusia maupun fakta sosial berupa ulah positif-negatif dari tingkah laku manusia.

Dalam khazanah budaya Islam, sastra Islam, ataupun apa namanya; sastra profetik, sastra sufi, dan sastra transenden tak lepas dari tiga hal yang mesti terkandung di dalamnya. Ketiga hal tersebut meliputi, pertama, kandungan yang menyeru kepada berbuat baik kepada siapapun dan untuk apapun. Kedua, mengajak dan menggiring manusia agar timbul pemahaman pentingnya menjauhi perbuatan yang tidak baik atau tidak bermanfaat bagi siapapun dan bagi apapun. Kedua hal ini sudah cukup untuk memenuhi kriteria sebagai sastra yang islami dalam konteks sosial, 
karena hanya pada kedua hal itulah ukuran suatu perkataan atau perbuatan baik dan tidak, bermanfaat atau tidak. Kedua hal itu dibahas dalam ungkapan al-Qur'an dengan “Amar ma'ruf nahi munkar. Namun kiranya belum sempurna sebagai konsekuensi dari pribadi beragama kalau tujuan dari semua tindakan tidak diorientasikan kepada Yang Maha Memiliki, Tuhan Yang Maha Esa. Karena itu, sebagai syarat ketiga untuk terpenuhinya kriteria sastra Islam adalah nilai transendensinya, yaitu sebuah nilai spiritual dari semua tindakan yang ditujukan dan diabdikan kepada Tuhan "iman kepada Allah".

Pada kurun waktu yang lalu, dalam konteks keindonesiaan, perkembangan intelektual Muslim telah memberikan kontribusi sangat besar terhadap pengayaan khazanah intelektual dalam bidang bahasa, sastra dan agama tentunya. Dalam hal ini, sastra yang telah diwarnai dengan nilai Islam biasa disebut dengan sastra keagamaan atau bahkan disebut dengan sastra Islam. Ada tiga corak sastra keagamaan dalam kurun waktu lalu hingga akhir abad 20, yaitu ; sastra rekaan, sastra kesejarahan dan sastra kitab.

Sastra rekaan umumnya berupa cerita fiksi yang biasa juga disebut hikayat atau matsal dalam istilah kesastraan Arab di masa Jahili hingga kini. Contoh untuk corak hikayat ini adalah Hikayat Banjar, Hikayat Raja Handak, Hikayat Raja Jumjumah dan lain sebagainya. Adapun contoh untuk Sastra Arab yang bercorak matsal adalah Kalilah wa Dimnah karya Ibn al-Muqaffa, Kitab al-Bukhala karya al-Jahidh, Hay bin Yaqdhan karya Ibn Thufail, Manthiq al-Thair karya Fariduddin al-Atthar dan lain sebagainya. Corak kedua, sastra kesejarahan merupakan sastra yang di dalamnya tercermin peristiwa-peristiwa sejarah. Hikayat Amir Hamzah, Hikayat Iskandar Zulkarnain, Hikayat Muhammad Hanafiyah Hikayat Saif Dzul Yazan adalah contoh untuk sastra corak kesejarahan ini. Pada umumnya sastra kesejarahan berisi peristiwa sejarah penyebaran Islam dan sejarah raja-raja Islam. Adapun yang masuk dalam kategori sastra kitab adalah sastra yang isinya berkisar pada ilmu fiqih, tasawuf, dan ilmu kalam. Yang termasuk dalam kategori sastra ini dalam sejarah kesastraan Nusantara adalah karya-karya dari Nuruddin Ar-Raniri, Hamzah Fansuri, Syamsuddin As-Sumatrani, Abdus Shamad Al-Falimbani dan lain sebagainya. Tujuan dari penulisan sastra Kitab adalah menanamkan ajaran atau nilai-nilai Islam sebagai basis penguat Iman di samping juga untuk meluruskan ajaran-ajaran yang menurut keyakinan penulisnya dianggap sebagai ajaran yang kurang benar.(Thoha, 2002:18)

Di jazirah Arab yang menjadi tanah tempat kelahiran Islam, sastra Islam yang bercorak tasawuf dan kezuhudan telah lahir dan berkembang kurang lebih dua belas abad yang lalu, karena memang tasawuf sebagai ilmu yang mandiri baru lahir pada abad kedua terakhir dari kalender Hijriyah. Dengan adopsi yang kreatif dari berbagai budaya dan pemikiran yang telah berkembang sebelumnya di luar Arab, para ulama dengan berbagai disiplin keilmuan berhasil memperkaya khazanah keilmuan Islam. Salah satu di antaranya adalah wacana ketasawufan yang tidak hanya berkutat pada doktrin-doktrin ortodoks yang fiqih minded atau teologi sunni dengan penekanan pada aspek akhlak dan amaliyah keseharian belaka. Tatapi telah berkembang jauh ke ranah filosofis akibat gesekan langsung dengan masyarakat yang telah memiliki peradaban maju seperti Persia, Mesir dan Yunani. Ajaran atau doktrin ketasawufan itu dapat diakses dari berbagai sumber secara langsung maupun tidak langsung. Berikut ini penulis akan menyampaikan beberapa untaian syair yang darinya dapat diungkap beberapa hal yang berkaitan dengan terma-terma ketasawufan, terutama pada pemikiran spekulatif yang akan memperkaya wawasan dan "memperindah" amal. Termasuk aplikasi hasil pemikiran tersebut yang diorientasikan pada tiga sumber kearifan : Tuhan, alam semesta, dan manusia. Ada tiga sumber yang dijadikan rujukan utama untuk penulisan ini, Al-Risalah al-Qusyairiyah karangan Syekh al- 
Qusyairi, Iqhad al-Himam fi Syarh al-Hikam karangan Syekh al-Ujaibah, dan buku sastra alTarikh al-Adabi fi al-Ashr al-Abbasyi al-Tsani karangan Syauqi Dhaif.

\section{Makna Tasawuf}

Sebuah pengertian, ta'rif atau definisi tidak ada yang mutlak selama orang lain mempunyai hak untuk memberikan pengertian juga. Demikian halnya dengan pengertian tasawuf, bahkan mungkin juga Islam, likulli ra'sin ra'yun “setiap kepala memiliki pemikiran”. Tentang Islam, kalau bertanya kepada ahli fiqih akan dijawab dengan sederet jawaban yang menggambarkan kewajiban seorang muslim yang berkaitan dengan rukun Islam, yaitu; dua ucapan syahadah, menegakkan shalat hingga kewajiban menunaikan ibadah Haji. Kalau ditanyakan kepada Mutakallimun, yaitu ulama ahli ilmu kalam atau teologi Islam, akan dijawab dengan beragam konsep tentang Tuhan dan bermacam sifat wajib, jaiz dan mustahil-Nya. Kalau kepada ahli kebatinan atau kejawen akan beda lagi, ia akan menjawab kurang lebih sama dengan pengertian agama yaitu "Trima mawi pasrah, suwung pamrih tebih ajrih" dengan tetap berlandaskan pada saringat (syariat). Beragama Islam dalam pengertian Kejawen ini berarti menjalani kehidupan dengan hati yang pasrah tanpa diiringi pamrih yang bersifat material dan menjauhkan diri dari rasa takut kepada selain Gusti Allah. Bila merujuk kepada sumber utama hukum Islam, alQur'an, memang ditegaskan di sana bahwa agama yang diterima Allah hanyalah agama yang dilandasi dengan kepasrahan "Inna al-Diin "inda Allahi al-Islam", sesungguhnya agama yang diridhai Allah adalah Islam.

Demikian juga halnya dengan pengertian tasawuf, akan ditemukan beragam arti sesuai isi kepala dan pengalaman si pelaku. Bahkan Muhammad bin Ujaibah dalam kitab Iqadh al-Himam (membangkitkan harapan) mengatakan bahwa pengertian tasawuf sebanyak orang yang mendalami dan melakukan ajaran-ajaran ketasawufan, lebih dari dua ribu pengertian sesuai pengalaman spiritualnya masing-masing. Untuk menyebut sekian banyak pengertian tentunya tidak mungkin, dan memang di kitab tersebut juga tidak menyebutkannya sampai dua ribu. Karena itu, di sini hanya akan dituliskan beberapa saja yang dirasa mewakili dari beberapa pengertian yang umum. Umumnya kita akan mudah menganalogikan kehidupan tasawuf dengan tradisi mistik yang bercorak takhayul, atau gambaran kehidupan menggembel yang apatis, asosial, dan tekstual dalam memahami sebuah titah ayat qur'ani atau Hadits Nabi. Betulkah demikian?

Tasawuf adalah moralitas yang berhubungan dengan Tuhan dan makhluk-Nya, artinya, orang yang belajar bertasawuf dan ingin hidup dalam bingkainya sudah seharusnya mencerminkan etika dalam tata-pergaulan yang selalu dihiasi dengan keramahan dan keindahan budi dengan siapapun, karena ia meyakini Tuhan senantiasa menyertainya dalam segala tindakannya, "In lam takun taraahu fa innahu taraaka", kau (memang) tidak mampu melihat-Nya, tapi pastikan bahwa Dia selalu melihatmu, kata Nabi ketika menjelaskan "al-Ihsan". Bertasawuf adalah pola hidup yang senantiasa menerapkan moralitas luhur disertai dengan usaha keras menolak dan keluar dari moralitas dan kebiasaan yang buruk atau "Al-Dukhuul fii Khuluqin Siniyyin wa al-Khuruj min kulli khuluqin daniyyin". Orang yang belajar tasawuf, kata Syekh Ahmad bin Muhammad bin Ujaibah al-Husna, penganggit Iqadh al-Himam, syarh dari kitab tasawuf al-Hikam, merasa tidak memiliki apa-apa, karena semua yang ada, bahkan yang dianggap orang sebagai miliknya sebenarnya hanyalah titipan Tuhan. Merendahkan hati meskipun sebenarnya dia memiliki kedudukan yang tinggi, dan tidak senang publikasi untuk mempopulerkan diri meskipun sebenarnya ia sangat dikenal. Ini adalah tanda-tanda seorang sufi yang benar (al-Sufiy alShadiq). Sebaliknya, jika ia merasa memiliki (titipan-titipan itu) hingga ia merasa begitu sedih 
saat berpisah dengannya (pindah tangan atau hilang), begitu ambisius dalam mengejar pupularitas atau ketenaran, dan merasa diri sebagai orang mulia yang butuh penyikapan yang berbeda dengan orang kebanyakan kalau berhadapan dengannya, maka yakinkan bahwa ketiga hal itu merupakan tanda-tanda sufi gadungan. Demikian kata Abu Hamzah al-Baghdadi (AlHusna, 1266 H.:4-5).

$$
\text { "الصوفى الكاذب ان يستغنى بعد الفقر ويشتهر بعد الخفاء ويعزٌ بعد الذل" }
$$

Bertasawuf bukan berarti meninggalkan dunia, tapi tetap berada di dalamnya dengan menggenggam erat dan mengamalkan ajaran-ajaran tasawuf. Senantiasa bertaubat karena berbuat salah atau dosa, bahkan dari kelalaian sedetik akan Kuasa Tuhan, zuhud, wara', sabar dan cinta adalah sebagia dari ajaran-ajaran tasawuf yang tidak boleh ditinggalkan dalam keadaan bagaimanapun. Sebagai contoh zuhud, kebanyakan kita mengartikan dengan meninggalkan dunia dan menjauhinya. Pengertian demikian kurang benar karena akan menjerumuskan orang kebanyakan pada kesengsaraan sosial yang akan "mengganggu" ritual-teologisnya dan justru akan menggiring umat pada posisi yang lemah dan menjadi "terjajah". Padahal umat yang kuat lebih baik dan lebih utama daripada umat yang lemah dalam segala hal, sitiran Nabi dalam sebuah haditsnya. Umat Islam harus kuat, karena itu harus menguasai dunia, namun tetap harus zuhud. Artinya apa, mereka harus memegang dan mengendalikan dunia tanpa harus dikuasai olehnya melalui ungkapan:

$$
\text { ضع الأنّيا فى يدك و لا تضع فى قلبك }
$$

Artinya: "Letakkan dunia di tanganmu dan jangan letakkan ia di hatimu".

Dengan demikian zuhud berarti proporsional dalam menempatkan sesuatu dan dalam hal ini adalah dunia, jangan sampai jiwanya dipenuhi dengan sifat meterialisme yang kini menjadi hantu dunia.

Ada sebuah kisah, Syekh Syaqiq al-Balkhi datang kepada Ibrahim bin Adham ingin belajar tasawuf. Sebelum merubah haluan ke taswuf al-Balkhi adalah seorang saudagar kaya yang senantiasa melakukan perjalanan dari satu tempat ke tempat lain untuk mengambil dan menjual barang dagangan. Dalam perhentian di tengah perjalanannya, ia menyaksikan seekor burung yang tak mampu terbang karena patah sayapnya. Seketika ia berpikir bagaimana burung ini akan mampu bertahan hidup tanpa sayap yang mengantarnya bepergian ke sana ke mari untuk memenuhi kebutuhannya. Di tengah kebingungannya memikirkan masa depan si burung nahas, tiba-tiba datang burung lain yang mengantar makanan dan langsung menyuapkan ke paruhnya. Peristiwa itu menginspirasi Syekh al-Balkhi untuk merubah dirinya menjadi seorang "sufi " yang tidak perlu menyibukkan diri dengan urusan materi. Ketika hal itu dilaporkan kepada Ibrahim bin Adham, sang Guru menanggapinya dengan berucap, "Kenapa kau tidak berpikir mengenai burung yang membawa makanan lalu menyuapkannya kepada sang burung malang ?

Dari kisah di atas dapat diambil pelajaran bahwa menjadi seorang sufi tidak harus menggembel, hidup susah atau malah menyusahkan sambil menampak-nampakkan diri sebagai pribadi yang paling dekat dengan Tuhan, lalu menampik segala beban kemanusian yang memang menjadi fitrah kehidupan sebagai khalifah Allah fi ardlihi. Sungguh luhur ajaran tasawuf yang melekat kuat dalam sanubari, ia mengajarkan kesucian hati dengan melepaskan diri dari perasaan memiliki terhadap dunia dan hal-hal yang berkaitan dengannya tanpa harus melarikan diri darinya untuk ikut mengatur dalam segala aktivitas yang memungkinkan si sufi terlibat dengan kompetensi yang dilimiki. Karena itu, mungkin saja ia seorang pebisnis seperti Manshur al- 
Hallaj, Aththar, Omar Khayyam, tetapi mereka adalah para sufi. Mungkin ia seorang negarawan seperti Umar bin Abdul Azis, mungkin seorang ilmuan seperti Jabir bin Hayyan, atau orang biasa saja tanpa status tertentu yang menandakan keunggulannya dibanding yang lain, seperti Uwais al-Qarni. Dan untuk situasi kita saat ini, di mana profesi semakin beragam dan menuntut spesifikasi tertentu, sufi bisa jadi seorang musisi, lawyer, politisi dan apapun, bahkan pemungut rongsokan sekalipun selama hati dan amalnya lurus. Mereka adalah orang-orang biasa, seperti orang kebanyakan, namun hatinya senantiasa berdzikir dan dzikir itu mewujudkan eksistensinya dalam aktivitas terkendali menuju Tuhan, bersama Tuhan dan selalu dalam Tuhan.

Perdebatan tentang asal-usul kata sufi tidak akan pernah sampai pada titik kesepakatan, karena ia memang jelmaan dari berbagai tradisi dan budaya. Demikian juga menyangkut praktik ritual yang lekat dalam gerakan-gerakan jamiyah thariqah yang diidentikkan dengan tasawuf, datang dan diadopsi dari tradisi dan ritual agama-agama sebelum Islam. Orang-orang berbeda pendapat karena mereka tidak tahu mengenai kata sufi, mereka menyangka ia berasal dari istilah suf (kain wol atau bulu domba). Padahal sufi yang hakiki adalah orang yang hatinya bersih, dan hati memang merupakan pusat eksistensi yang hakiki dari manusia.

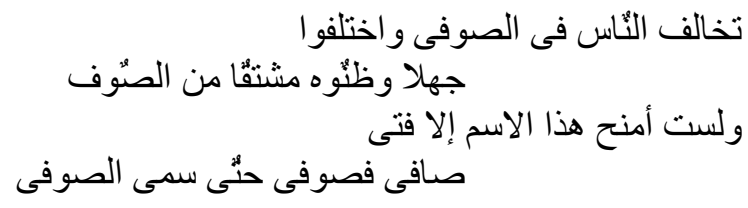

Artinya: "Orang-orang berbeda pendapat tentang kata sufi. Mereka, karena tidak tahu (jahl) mengira nama sufi berasal dari kain wol kasar (suuf). Saya tidak memberi sebutan sufi kepada seorang pemuda kecuali jika ia bersih (hatinya), itulah sebenarnya sufi."

Jadi, biarlah perbedaan ini menjadi wacana untuk memperkaya wawasan, namun jangan melupakan substansinya bahwa tasawuf diorientasikan pada penataan hati demi terbentuknya pribadi luhur yang ke manapun pergi menjunjung dan menebarkan nilai Islam, berdakwah mengajak kepada kebenaran yang maslahah, menjauhi hal-hal yang merusak dan menanamkan iman ke lubuk setiap insan. Keimanan terhadap adanya Tuhan akan membawa optimisme tersendiri bahwa kegagalan meraih harapan hanyalah ujian Tuhan untuk mematangkan jiwa agar tidak putus asa ketika belum mampu meraihnya dan tidak lupa diri ketika sudah mampu menggapainya. Sembari terus berusaha keras, mereka yang memahami tasawuf akan dilingkupi optimisme bahwa hari esok lebih cerah. Kalaupun harapan yang diekspresikan dengan do'a belum terpenuhi, itu bukan berarti tidak terkabul, tapi Allah menundanya dan do'a itu sendiri memang menjadi catatan kebaikan yang pada saatnya akan diganjar.

Dalam hubungannya dengan sastra, sastra sufi adalah sastra yang mengajak kepada tiga hal pokok yang telah disinggung di atas; amar ma'ruf, nahi munkar dan percaya adanya Tuhan. Ketiga hal itu dijabarkan lebih lanjut oleh Junaid al-Baghdady dengan delapan prinsip yang mesti dipegang teguh dan disebar-luaskan, yaitu; Kebebasan seperti Ibrahim, penerimaan terhadap nasib seperti Ismail, Kesabaran seperti yang dimiliki Ayyub, Kemampuan berkomunikasi secara simbolis seperti Zakaria, pengasingan diri dari orang-orangnya sendiri seperti Yunus, pakaian wol (kasar) seperti penggembalaan Musa, perjalanan pengembaraan seperti Isa, dan kerendahan hati seperti semangat humanisme Muhammad. (Shah, 1990:246) Tasawuf memang jalan universal yang dengannya Islam dapat merambah ke berbagai aspek 
kehidupan manusia, mewarnai dunia yang makin gelap ini dengan wajah Tuhan, hingga kehidupan jadi terang dan dunia aman tentram.

\section{Ajaran Sufi Dalam Untaian Syair}

Tasawuf menjadi sesuatu yang amat urgen dalam beragama, karena tanpanya keberagamaan seseorang akan kering, kurang sempurna dan baginya ajaran agama tidak ubahnya sederetan aturan acara ritual yang dilakukan pemeluknya hanya demi mendapat imbalan surga atau kebebasan dari adzab neraka. Mereka yang tidak mengenal tasawuf akan melihat dunia ini dipenuhi kegelapan yang kemudian melihat sesuatu dengan kacamata hitam-putih, hanya ada benar dan salah, tidak ada ruang untuk pemahaman bahwa dalam kebenaran masih ada kemungkinan kesalahan, pun demikian sebaliknya. Perhatikan bait berikut :

$$
\begin{aligned}
& \text { ليلى بوجهك مشرق } \square \text { وظلامه فى النّاس سارى }
\end{aligned}
$$

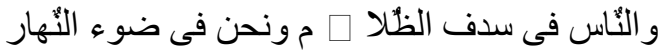

"Malamku di hadapan-Mu seperti terang mentari, sementara mereka dalam kegelapan. Mereka berada di balai kegelapan tanpa cahaya, sedangkan kita dalam suasana terang seperti siang".

Hal yang utama perlu mendapat perhatian dalam hidup ini, agar selalu dalam suasana terang dan bergairah adalah kehadiran Tuhan dalam setiap aktivitas, baik fisik maupun psikis. Dalam perspektif tasawuf, suatu perbuatan atau amal tidak bisa hanya dilihat dari wujud yang terlihat saja untuk menyebut baik atau tidak, namun juga perlu dilihat aspek dalam yang memotivasinya, yaitu dari niat yang tersimpan di hati. Oleh karena itu, bisa jadi suatu perbuatan yang kalau dilihat status kualifikasi materialnya sama akan memiliki status nilai yang berbeda karena perbedaan niat. "Banyak amal yang berwujud amal akhirat hanya menjadi amal duniawi karena niat yang keliru, dan tidak sedikit amal yang berwujud amal duniawi menjadi amal akhirat karena niat yang benar (ikhlas)," kata Nabi. Di tempat yang lain, Nabi menegaskan agar umatnya melakukan perbuatan-perbuatan baik, karena perbuatan itulah nanti yang mengantarkannya ke surga. Namun demikian jangan bronto dulu , karena surga atau neraka itu adalah hak prerogative Allah. "Bukan karena amalnya seseorang masuk surga, tapi karena kasih sayang Allah". Demikian rambu-rambu Nabi agar umatnya tidak takabbur (Al-Husna, 1266 H.:12-14)

Tuhan adalah prinsip asal dari segala yang ada (maujudat) dan Dia wajib adanya (Wajib alwujud), sedangkan yang lain, yang disebut alam atau makhluq, hanyalah mungkin adanya (mumkin al-wujud). Tuhan disebut al-Ghani karena keberadaan-Nya yang tidak membutuhkan apapun, sementara alam ini adalah al-faqir karena ia mustahil mampu menyelenggarakan atau mengadakan dirinya sendiri, ia pasti membutuhkan Pembentuk yang mewujudkan eksistensinya. Sifat Tuhan yang paling esensial adalah Esa, meskipun Ia bisa saja disebut memiliki sifat-sifat, namun sifat-sifat itu tidak selalu harus digambarkan sebagai tambahan kepada dzat-Nya karena hal ini akan mengesankan adanya komposisi (tarkib) pada diri Tuhan. Keesaan Tuhan tercermin dalam kesatuan sistem perintah (amr) yang mengendalikan alam semesta. Kenyataan bahwa hanya ada satu sistem yang berlaku di alam semesta ini menunjukkan keesaan pemberi perintah, yaitu sang Pencipta (al-Khaliq) yang dalam hal ini Allah Subhaanahu wa Ta'ala. Seandainya ada dua sistem, maka sudah pasti akan ada dua sistem kontrol. Kalau ada dua sistem kontrol, sudah pasti tidak ada harmoni dan terjadi chaos, bukan Kosmos. Kalau sudah demikian, maka akan terjadi perseteruan dua kekuatan besar yang akan menyebabkan kerusakan dan kehancuran alam semesta. (QS al-Anbiya' 22 ) 
Keesaan Tuhan tidak tergambar dengan apapun, dan pengenalan manusia terhadap-Nya yang hanya dengan perantara akal akan menggiring kepada kekeliruan. Pengetahuan manusia tentang Tuhan, meskipun melalui Wahyu-Nya yang memang merupakan buku panduan utama hanya bersifat majazi (alegoris) dan tidak bisa disebut mutlak. Maha suci Allah dari segala apa yang digambarkan manusia tentang-Nya. Ali bin Abu Thalib berkata: (Al-Husna, 1266 H.:52)

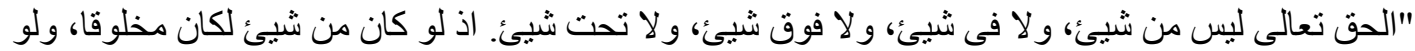

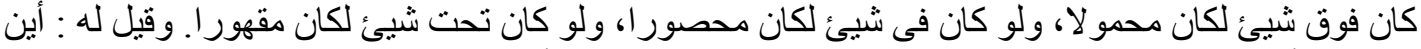

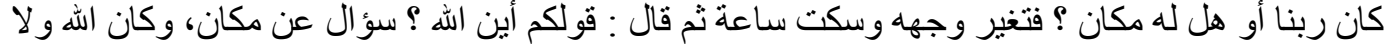

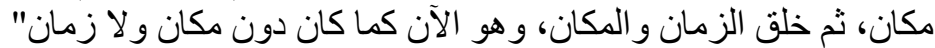

Betapapun canggih dan abstraknya pemerian manusia tentang Tuhan hingga melahirkan konsepkonsep yang tidak terbantah secara logika, tetap bersandar pada pengalaman empiris yang mesti selalu dipandang relatif. Oleh karena itu, manusia mesti meyakini bahwa hanya wahyu atau ayatayat Tuhan saja yang bersifat mutlak dan abadi, sedangkan hasil pemikiran tentangnya tetap harus dipandang sebagai tafsir yang nisbi (relatif-temporal). Bagi kaum sufi, Tuhan sangat memiliki perhatian terhadap kelangsungan dan kesejahteraan makhluk-makhluk-Nya. Sangat akrab dan dekat hingga senantiasa mendengar setiap saat keluhan hamba-hamba-Nya yang terlantun dalam senandung do'a dan puja-puji. Meskipun begitu dekat dengan-Nya, namun kedekatan itu tidak membawa sang sufi kepada sikap jumawa dengan memaklumkan kedekatan tersebut kepada khalayak ramai, apalagi sampai melahirkan sikap takabur secara teologis di mana orang yang tidak seirama dengannya dianggap berada di jalan yang sesat. Dalam hal ini, mereka berprinsip (Al-Husna, 1266 H.:49).

$$
\text { ولى حبيب عزيز لا أبوح به فضيحة وجهى يوم ألقاه }
$$

"Bagiku Kekasih yang sangat Agung, tidak akan kupamerkan. (kalau kupamerkan) Aku khawatir Dia membuka aibku saat bertemu dengan-Nya"

Tuhan sangat mengasihi makhluk-makhluk-Nya. Wujud kasih sayang Tuhan itu tercermin dari nikmat-Nya yang tiada terhingga, suatu nikmat yang tiada pernah mampu dibilang oleh manusia sampai kapanpun. Salah satu kenikmatan itu adalah kehidupan ini sendiri, yaitu kehidupan yang dimiliki manusia. Udara yang dibutuhkan oleh sistem pernapasan tubuh maupun sirkulasi darah, panas matahari untuk menghangatkan tubuh dan untuk pertumbuhan makhluk-makhluk lain, air dan api untuk berbagai keperluan dan juga berbagai jenis makanan dari tumbuh-tumbuhan dan hewan adalah sekian deret kenikmatan yang teramat panjang dan jelas tidak mampu bila diuraikan satu persatu. Dengan demikian, gugusan kenikmatan yang berlimpah tersebut cukuplah sebagai bukti tak terbantahkan akan kebijaksanaan dan kasih sayang Tuhan kepada makhlukNya, terutama manusia.

Dengan menyadari kemaha-Agungan dan kasih sayang Tuhan, melaksanakan kewajiban yang dikenakan berupa amal perbuatan yang baik dan bermanfaat dan menjauhi yang dilarang karena mendatangkan kerusakan dan kesengsaraan adalah satu-satunya jalan keselamatan yang mesti dilakukan untuk mencapai kebahagiaan. Ibarat berjalan di tengah padang atau hutan belantara, orang yang telah terbukti kasih sayangnya akan diikuti petunjuk-petunjuknya agar tidak tersesat di tengah padang atau hutan belantara tersebut. Selain dari itu, kewajiban tersebut jangan sampai dianggap sebagai balas budi kepada-Nya, karena Tuhan tidak membutuhkan hal itu. Juga sangat tidak benar kalau kewajiban itu dianggap sebagai paksaan. Memenuhi apa yang dititahkan Tuhan 
kepada manusia tidak lain merupakan ungkapan rasa syukur atas berbagai nikmat yang telah dikaruniakan kepada kita.

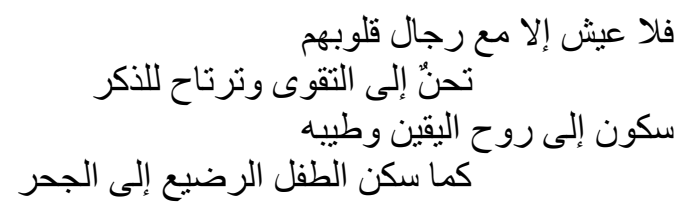

"Tidak ada kehidupan kecuali bersama orang-orang yang hatinya selalu rindu pada ketaqwaan dan bahagia karena (selalu dalam) dzikir. Bersama orang-orang yang jiwanya tenang karena kepercayaan kepada tuntunan keyakinan (iman) dan kesuciannya, seperti tenanganya bayi menyusu (dalam dekapan) ibunya” (AlQusyairi, Tt ; 106)

Selain Tuhan yang menjadi pembahasan tasawuf, alam semesta juga merupakan aspek yang tidak boleh diabaikan, karena ia menjadi lokus Tajalliyat dari sifat Jamalihah-Nya. Alam semesta tidak lain adalah tanda tanda (ayat) dari kekuasaan dan kebesaran Tuhan. Alam semesta bukanlah realitas terakhir sebagaimana yang disangkakan oleh para ilmuan alam (positivis) yang sekular atau bahkan ateis. Dengan mempelajari tanda-tanda Tuhan tersebut, seorang ilmuan mestinya dapat menunjukkan adanya Tuhan selanjutnya mendekat pada-Nya. Alam semesta terwujud bukan keniscayaan dalam arti sudah ada sejak semula, seperti anggapan sebagian filosof (Neoplatonis). Tetapi dia diadakan atau diciptakan dengan sengaja dan terencana oleh kehendak bebas Tuhan Yang Mutlak. Karena alam diciptakan dari ketiadaan (creation ex nihilo) maka ia sudah pasti tidak akan abadi seperti yang disangkakan kaum filosof juga. Karena alam adalah bidang kreativitas Tuhan, mempelajarinya sama halnya dengan mempelajari sifat-sifat Tuhan. Al-Hallaj dalam al-Thawasiin bersenandung :

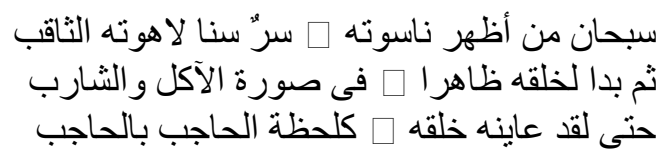

"Maha suci Dzat yang ruh kemanusiaan-Nya dengan bahagia mengurai dalam Ruh ketuhanan Yang Cerdas. Lalu menampakkan diri demi makhluk-Nya dalam rupa makhluk yang membutuhkan makan dan minum. Sungguh Ia menyaksikan dalam diri makhluk itu (manusia) sekilas wujud-Nya. (Dhaif, 1973:479)

Alam ini diatur melalui apa yang disebut al-Qur'an dengan Sunnah Allah. Sunah Allah bukanlah hukum alam (natural law) seperti anggapan umum yang sudah populer, tetapi suatu ketentuan Allah untuk suatu sistem atau proses tertentu yang berada sepenuhnya di tangan (kekuasaan) Allah. Dengan meyakini bahwa segala sistem yang berhubungan dengan alam semesta, mulai kuman (terkecil) hingga gugusan bintang-bintang (tata surya) ini berada di Tangan Allah, maka keyakinan tersebut tidak akan memungkiri peristiwa apapun dengan idzin dan kreativitas Allah. Sunnah Allah adalah cara atau kebiasaan Allah dalam proses penyelenggaraan alam. Karena sepenuhnya di tangan Allah, Hukum yang disebut Sunnah Allah tidak menafikan Mu'jizat, sementara natural law sama sekali tidak memberi tempat untuk kejadian-kejadian luar biasa yang biasanya diberikan Allah kepada Hamba-hamba-Nya yang terpilih, yaitu para Nabi atau Wali.

Alam diciptakan tidak lain untuk menunjukkan kebesaran Tuhan. Dalam al-Qur;an berkali-kali disebutkan agar manusia memperhatikan fenomena alam yang amat indah dan menyimpan 
keajaiban tertentu sebagai bukti kebesaran-Nya. "Maka apakah mereka tidak memperhatikan unta bagaimana ia diciptakan, memperhatikan langit bagaimana ia ditinggikan, gunung-gunung bagaima dikukuhkan, bumi (tanah) bagaimana ia dihamparkan. Maka berilah peringatan! (alGhasyiyah). Tuhan menunjukkan tanda-tanda-Nya pada jagad raya dan juga pada diri manusia. Dengan bahasa lain, di seluruh tingkat wujud yang ada dan membentuk alam semesta ini adalah tanda-tanda (ayat) Allah, dan tanda-tanda itu, tentu saja menunjukkan pada yang ditandai atau mencerminkan sifat-sifat-Nya. Oleh karena itu, menurut para sufi, alam semesta ini merupakan cermin universal di mana Tuhan kemudian terlihat padanya, kata al-Hallaj( Dhaif, 1973:479)

Di atas keagungan dan keindahan semua ciptaan Tuhan (alam - makhluk), manusia menempati kedudukan paling utama. Inilah pembicaraan yang juga menjadi tema penting di kalangan kaum sufi. Cermin paling representatif bagi Tuhan pada makhluk-Nya hanyalah manusia, karena pada diri manusia terkandung semua unsur yang membentuk alam semesta. Masing-masing unsur memiliki daya istimewa mulai dari unsur mineral, tumbuh-tumbuhan, hewan, dan manusia itu sendiri. Karena mengandung semua unsur yang membentuk alam semesta itulah (makrokosmos) maka manusia sering disebut "mikrokosmos". Dengan demikian manusia adalah cermin potensial bagi sifat-sifat Tuhan, di mana sifat-sifat tersebut di luar diri manusia terpantul secara fragmenter di dalam aneka tingkat wujud yang terpisah-pisah. Inilah makna yang terkandung dalam firman-Nya (hadits Qudsyi): "Sesungguhnya Allah menciptakan Adam dalam bentukNya" (Dhaif, 1973:479).

Keistimewaan yang dianugerahkan Tuhan pada manusia tergambar dari proses penciptaannya, di mana ketika usai terbentuk wujud fisik manusia Tuhan meniupkan ruh padanya. Oleh karena itu, manusia memiliki dua dimensi yang membentuk sebuah entitas yang disebut al-nafs, yaitu dimensi jasmani dan rohani. Sebagai makhluk rohani manusia mampu melakukan hal-hal yang tidak mampu dilakukan makhluk lainnya, seperti menerima wahyu atau ilham, melanjutkan kehidupan setelah kamatian, melakukan perenungan abstrak dan mengetahui al-ma'qulat, yaitu hal-hal yang hanya bisa dipahami lewat akal dan intuisi, bukan saja yang hanya bisa ditangkap dengan indra (Kertanagara, 2007:13). Begitu istimewa kualitas yang membentuk manusia, maka Tuhan menjadikannya sebagai khalifah atau wakil-Nya di muka bumi ini. Karena itu, sudah sewajarnya apapun yang ada di alam ini menjadi inspirasi untuk selalu ingat Tuhan (dzikir) dalam segala aktivitas.

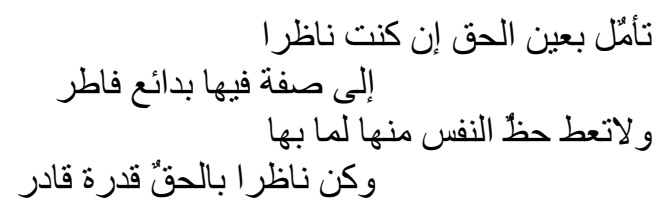

"Berpikirlah tentang Kekuasaan Allah, kau lihat keindahan-keindahan (semesta) yang diciptakan-Nya. Jangan kau beri kesempatan nafsu mengganngu perenunganmu, teruslah bertafakkur tentang-Nya seperti orang yang telah mampu melakukan". (Kertanagara, 2007:476)

Sebagai wakil-Nya, manusia telah dibekali dengan dua anugerah yang amat istimewa berupa akal rasional dan kebebasan. Akal yang dianugerahkan Tuhan kepada manusia dinyatakan dalam al-Qur'an dengan ungkapan bahwa Allah mengajarkan nama-nama kepada Adam, nenek moyang manusia. Nama-nama yang disebutkan itu tidak lain adalah prototype penegetahuan yang terus berkembang seiring dengan kemajuan jaman. Karena itu manusia berpotensi mengetahui seluruh tatanan realitas, baik yang bersifat fisik maupun matafisik. Pengetahuan terhadap benda-benda 
fisik atau al-mahsusat dapat dilakukan melalui panca indra atau persepsi indrawi yang demi validnya disempurnakan dengan metode observasi dan eksperimen. Selain karunia panca idra untuk mengenali realitas fisik, manusia dengan akalnya mampu menerobos batas-batas indrawi sehingga mampu menangkap obyek-obyek non-material atau yang biasa disebut al-ma'qulat, yaitu obyek-obyek yang hanya bisa dikenali melalui akal.

Adapun anugerah kebebasan sudah tentu bersandar pada kenyataan bahwa manusia adalah makhluk rohani yang dengan kualitas istimewa dari hembusan roh Tuhan itu mampu untuk tidak sepenuhnya tunduk pada hukum-hukum yang berlaku di alam fisik. Dengan anugerah itu, manusia menjadi makhluk moral yang bisa diberi sifat baik atau jahat, tergantung perbuatan mana yang dipilih dengan penuh kesadarannya. Manusia tidak dipaksa untuk melakukan suatu perbuatan tertentu sebagai konsekuensi dari akal yang telah diberikan, tetapi ia diberi kebebasan untuk memilih. Selanjutnya pilihan tersebut punya konsekuensi tertentu sesuai dengan pilihan baik buruk, bahagia dan sengsara. Seandainya manusia tidak diberi kebebasan untuk memilih, berarti ia telah ditentukan sebelumnya, dan bila ini yang terjadi berarti manusia tidak mempunyai kekuatan apapun terhadap apa yang dilakukan, tidak mampu mengubah kondisi, tidak mampu mewarnai kehidupannya sendiri. Dengan demikian keberadaan manusia di alam ini tidak ubahnya benda mati yang mungkin saja dapat dimanfaatkan kalau ada yang mau memanfaatkan, atau tergeletak tanpa makna karena tidak ada yang mengetahui dan memanfaatkan. Lebih jauh, kalau tidak ada kebebasan buat apa di al-Qur'an berulang-ulang Allah menjanjikan surga bagi yang beramal baik dan neraka bagi yang beramal sebaliknya. Meskipun untuk beramal baik dengan harapan surga sungguh kurang terpuji dalam pandangan kaum sufi. Beramal dan beribadah tidak lain haruslah demi Allah itu sendiri, inilah yang benar bagi sufi.

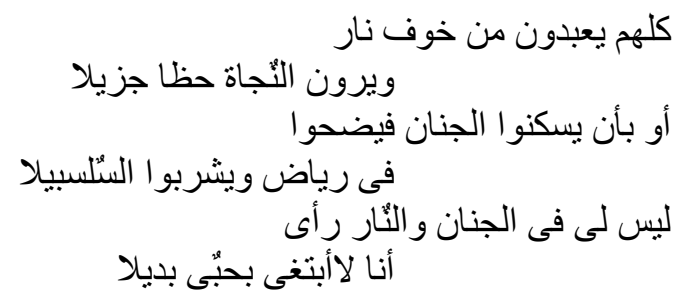

"Mereka beribadah karena takut neraka dan mengharap mendapat keselamatan dengan bagian berlimpah, atau mengharap bisa tinggal di surga berada di taman sambil minum dari telaga Salsabila. Bukanlah hal itu yang saya harapkan, (bagiku) tidak ada yang dapat mengganti cinta (untuk menemukan Kekasih)". (Ibn Ujaibah,

32)

Derajat kemulian yang dianugerahkan Tuhan kepada manusia menjadikannya memiliki posisi luhur yang sampai batas tertentu memiliki kesamaan dengan penciptanya. Karena itu, tidak keliru jika Manshur al-Hallaj menyatakan sebagai ungkapan kemenyatuan Ruh Tuhan dengan dirinya :

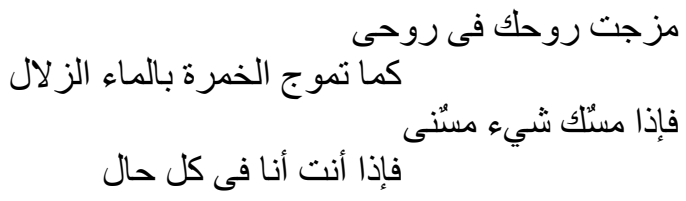

"Ruh-Mu telah bercampur jadi satu dalam diriku seperti bercampurnya perasan anggur dengan airnya, Jika sesuatu (sifat) ada pada-Mu aku juga begitu, maka (segala 
yang ada pada) Kau adalah (sesuatu yang juga harus ada pada) aku dalam segala hal".

Agar posisi yang begitu mulia itu tidak mengalami degradasi akibat sikap dan orientasi yang tidak menyasar kepada pokok aturan yang telah dititahkan Tuhan sebagai acuan menuju terciptanya manusia baik (insan kamil) sebagaimana yang diidamkan setiap hamba yang Shalih, maka manusia harus bisa menepis bujuk rayu godaan nafsu yang menjelma dalam wujud usahausaha menipiskan keyakinan untuk kemudian diseret pada jurang keraguan akan Kuasa Tuhan pada segala yang ada di alam ini. Termasuk kuasa Tuhan terhadap yang dialami manusia sendiri akan apa yang diraih. "Siapa yang menganggap dengan usahanya akan sampai pada apa yang dituju dia terpedaya, dan siapa yang menganggap tanpa usaha tertentu akan sampai pada maksud yang dituju dia adalah pemimpi", kata sebuah ungkapan bijak. Dengan demikian, tasawuf mengajarkan kearifan dalam hubungannya dengan Sang Khalik dan makhluk-Nya, termasuk untuk meraih kesuksesan fi-al-Darraini.

\section{Penutup}

Mengajak kepada jalan yang benar (berdakwah) adalah tugas pokok setiap muslim yang telah menyatakan janji setia pada Islam. Namun kesetiaan itu tidak boleh sampai melahirkan klaim bahwa satu-satunya kebenaran adalah ajaran yang ia anut, karena Islam memang berwarnawarni. Islam mengajak kepada kepasrahan pada Tuhan dengan menjalankan perintah dan menjauhi larangan-Nya. Seumpama rumah, pintu untuk masuk ke dalam rumah itu ada banyak bahkan mungkin ratusan bahkan ribuan. Para sufi punya cara sendiri untuk mengajak masuk ke dalamnya, mereka sering menggunakan cerita-cerita hikmah atau anekdot tertentu agar si pengingkar tidak merasa tertusuk, lalu dengan sepenuhnya insaf dan sukarela tanpa rasa terpaksa mengikuti ajakan sufi. Syair juga merupakan medium yang sangat efektif untuk menyelipkan nilai-nilai Islam dengan bungkus kebahasaan yang lebih universal. Karena itu, dengan syair itulah para sufi banyak menyeru ke jalan Tuhan.

Ada tiga hal dalam hidup ini di mana dengan ketiganya manusia selalu berinteraksi di manapun dan sampai kapanpun. Demikian juga, pada ketiga hal tersebut manusia harus selalu mengabdi sesuai dengan kadar dan porsi (Rahmat) kedekatannya. Ketiga hal itu adalah; Tuhan, alam, dan manusia. Meskipun secara ontologis "Yang Pertama" memiliki status lebih tinggi, tidak sedikit manusia yang mengingkari nikmat dan anugerah-Nya, bahkan eksistensi-Nya. Oleh karena itu, pada "Yang Pertama" itulah kaum sufi menyeru untuk selalu diingat dan dituju. Dua yang berikutnya sangat subyektif manusia memandang, tapi tidak demikian dengan kaum sufi. Keduanya mendapatkan porsi yang wajar bahkan hampir menyerupai Yang Pertama, karena keduanya memang menjadi lokus tajalliyah dan jamaliyah-Nya.

Demikianlah kaum sufi menjaga eksistensinya dengan membangun kearifan diri dalam bungkus humanisme universal supaya semua manusia masuk ke dalam (rumah) Islam dan mau menegakkokohkannya hingga akhir masa.

\section{DAFTAR PUSTAKA}

Agus, Bustanuddin. 2007. Agama dalam Kehidupan Manusia. Jakarta: RajaGrafindo Persada

Al-Husna, Ahmad bin Muhammad bin Ujaibah. 1266 H. Iqadh al-Himam fi Syarh al-Hikam. Jiddah: al-Haramain. 
Ali, Yunasril. 1997. Manusia Citra Ilahi. Jakarta: Paramadina

Al-Imam al-Ghazali. Tanpa tahun. Majmu'ah Rasa'il al-Imam al-Ghazali. Beirut: Daar al-Kutub al-Ilmiyah.

Al-Qusyairi, Abd al-Karim bin Hawazin. Tanpa tahun. al-Risalah al-Qusyairiyah fi Ilm alTashawwuf. Ditahqiq Ma'ruf Zariq dan Ali Abd al-Hamid. Tanpa tempat: Daar al-Khair.

Ambary, Hasan Muarif. 1998. Menemukan Peradaban Islam. Jakarta: Logos Wacana Ilmu.

Chitick, William C. 2001. Tuhan Sejati dan tuhan-tuhan Palsu. Terjemahan Achmad Nidjam dkk. Yogyakarta: Qalam.

Daftary, Farhad (Ed.) 2002. Tradisi-Tradisi Intelektual Islam. Terjemahan Fuad Jabali dan Udjang Thalib. Jakarta. Erlangga

Dhaif, Syauqi. 1973. Al-Tarikh al-Adab al-Ashr al-Abbasy. Kairo: Daar al-Ma'arif.

Hadi, Abdul W.M.. 1985. Sastra Sufi Sebuah Antologi. Jakarta: Pustaka Firdaus. Andre

Kailani, Najib. 1985. Rihlah ma'a al-Adab al-Islami. Beirut: Muassasah al-Risalah.

Kartanegara, Mulyadi. 2002. Menembus Batas Waktu: Panorama Filsafat Islam. Bandung: Mizan,

Khalid al-Walid. Tanpa tahun. Tasawuf Mulla Shadra : Konsep Ittihad al-Aqil wa al-Ma'qul dalam Epistimologi Filsafat Islam dan Makrifat Ilahiyah. Bandung: Muthahhari Press.

Kuntowijoyo. 2001. Muslim Tanpa Masjid. Yogyakarta : Mizan.

Muchtar, A. 2001. Tunduk Kepada Allah : Fungsi dan Peran Agama dalam Kehidupan Manusia. Jakarta. Khazanah Baru.

Muthahhari, Murtadha. 2007. Manusia dan Agama Membumikan Kitab Suci. Bandung: Mizan.

Nasr, Sayyed Hossein dkk. 2003. Warisan Sufi. Yogyakarta: Pustaka Sufi.

Qutub, Muhammad. 1987. Manhaj al-Fan al-Islami. Kairo: Daar al-Syuruq.

Rahmat, Jalaluddin. 2005. Psikologi Agama. Bandung. Mizan.

Schimmel, Annemarie. 2000. Dimensi Mistik Dalam Islam. Terj. Sapardi Djoko Damono dkk. Jakarta : Pustaka Firdaus.

Shah, Idris. 1990. The Way of the Sufi. London: Arkana/ Penguin.

Shihab, M. Quraish. 1996. Wawasan Al-Qur'an Bandung: Mizan.

Thoha, Zainal Arifin. 2002. Eksotisme Seni Budaya Islam. Yogyakarta: Bukulaela.

Zakiy, Ibrahim dkk. 1969. Da'irah al-Ma'arif al-Islamiyah. Kairo: Al-Sya'b. 